\title{
Effect of whole-milk allowance on liveweight gain and growth of parenchyma and fat pads in the mammary glands of dairy heifers at weaning
}

\author{
A. J. Molenaar, ${ }^{1}$ P. H. Maclean, ${ }^{1}$ M. L. Gilmour, ${ }^{2}$ I. G. Draganova, ${ }^{3}$ C. W. Symes, ${ }^{4 *}$ J. K. Margerison, ${ }^{5}$ \\ and C. D. McMahon ${ }^{6}$ \\ ${ }^{1}$ AgResearch Ltd., Grassland Research Centre, Private Bag 11008, Palmerston North 4410, New Zealand \\ ${ }^{2}$ Mark Gilmour Consulting Ltd., 443 Tutaenui Road, Marton 4788, New Zealand \\ ${ }^{3}$ School of Agriculture and Environment, Massey University, Private Bag 11 222, Palmerston North 4474, New Zealand \\ ${ }^{4}$ Catalyst Ltd., Christchurch, New Zealand 8245 \\ ${ }^{5}$ School of Bioscience, Division of Animal Science, University of Nottingham, Nr Loughborough, LE12 5RD, United Kingdom \\ ${ }^{6}$ ManukaMed LP, Ruakura Research Centre, 10 Bisley Rd, Hamilton 3214, New Zealand
}

\section{ABSTRACT}

The rates of development of 2 tissues in mammary glands, parenchyma (PAR) and the mammary fat pad (MFP), in response to nutrition in early life might have a major bearing on lifetime milk production. Historical studies reported that feeding greater amounts of dietary nutrients from postweaning to puberty increased growth rates of heifers and stimulated the growth of MFP at the expense of PAR, which might suggest compromised mammary development and future milk production. The current study sought to determine if a higher volume of whole milk ( 8 vs. $4 \mathrm{~L} / \mathrm{d}$ ) offered to calves would increase rates of growth and development of PAR in mammary glands at weaning (1 to 12 wk). To measure these tissues, we developed 2 simple methods to assess the size of PAR and MFP at the time of screening using ultrasound. We report that calves offered $8 \mathrm{~L} / \mathrm{d}$ of whole milk had greater rates of growth until weaning $(0.86 \pm 0.06$ vs. $0.81 \pm 0.09 \mathrm{~kg} / \mathrm{d})$, compared with calves offered $4 \mathrm{~L} / \mathrm{d}$. Ultrasonography showed that despite the faster rates of growth in calves offered $8 \mathrm{~L} / \mathrm{d}$ of milk/d, the ratio of PAR:MFP depth was $40 \%$ less at weaning in the front glands (34\%) compared with calves offered $4 \mathrm{~L}$ of milk/d. Rear glands were less impaired. The ultrasound methods developed here might be useful to monitor the development of mammary glands in response to different nutritional regimens during the preweaning period.

Key words: calf growth, mammary development, nutrition, ultrasound

Received June 18, 2019.

Accepted January 27, 2020.

*Corresponding author: wymond.symes@catalystnz.co.nz

\section{INTRODUCTION}

Higher levels of nutrition were once thought to compromise development of mammary glands from postweaning to puberty (Sejrsen et al., 1982; Sejrsen, 1994; Sejrsen and Purup, 1997). However, it is now understood that heifers reared on higher levels of nutrition not only have increased rates of growth, but also reach puberty and calve at a younger age, while having greater development of mammary glands (Brown et al., 2005; Meyer et al., 2006a,b; Daniels et al., 2009b), which was associated with greater yields of milk at first lactation (Moallem et al., 2010; Soberon et al., 2012; Soberon and Van Amburgh, 2013). Therefore, the preweaning period might confer a window of opportunity to improve both growth of the heifer and mammary glands to achieve greater lifetime milk production.

Although the conventional nutritional strategy for rearing heifers has been to feed milk or milk replacer at $10 \%$ of birth weight, others have shown that calves grow faster and wean at an earlier age when offered milk or milk replacer at up to $20 \%$ of birth weight, when offered whole milk or milk replacer ad libitum (Shamay et al., 2005; Khan et al., 2007; Moallem et al., 2010), or when whole milk with nutrients is added (Margerison et al., 2013). In addition, the faster rate of growth is often maintained postweaning and heifers reach puberty at a younger age, have increased skeletal frame scores (hip width and height, withers height, and heart girth), are heavier at conception, and either produce or have a tendency to produce greater volumes of milk in the first lactation in some (Shamay et al., 2005; Moallem et al., 2010; Korst et al., 2017), but not in all cases (Kiezebrink et al., 2015). Therefore, it is possible that offering calves a greater volume of milk preweaning might have a benefit to development of the mammary gland and for greater lifetime productivity of the cow in the herd. 
Ultrasound has increasingly been used in studies on mammary anatomy and milk storage (Bruckmaier and Blum, 1992; Ayadi et al., 2003; Franz et al., 2009), and to monitor the development of mammary glands of replacement heifers to understand what influence diet has on these tissues and to evaluate what influence changes in growth of these tissues have on subsequent lactation (Nishimura et al., 2011; Albino et al., 2015; Esselburn et al., 2015; Albino et al., 2017; Furini et al., 2018). Notably, the technique is noninvasive and has the potential to be objective. There are 2 principal types of tissues in mammary glands. The first type is the parenchyma (PAR), which is a stromal epithelial tissue that gives rise to ductal tissue and contains progenitor cells that give rise to the lobule-alveolar tissue during pregnancy, and the second type is the mammary fat pad (MFP), which includes loose connective tissue, blood vessels, and lymph vessels and serves as a matrix to support the growth of the ductal and secretory tissue (Knight and Peaker, 1982; Ellis and Capuco, 2002). These tissues have been shown to respond differentially to management (Collier et al., 2017) and nutrition (Brown et al., 2005; Meyer et al., 2006a,b; Daniels et al., 2009a; Geiger et al., 2016a,b). The current method of assessment of ultrasound images requires tracing around the respective PAR and MFP (Esselburn et al., 2015; Furini et al., 2018), which is both time and labor consuming.

The objective of the current study was to evaluate 2 new methods of assessing PAR and MFP using ultrasound of mammary glands of heifer calves offered a restricted ( $4 \mathrm{~L}$ per day $=10 \%$ of birth weight) or an increased amount ( $8 \mathrm{~L}$ per day $=20 \%$ of birth weight) of whole milk during the preweaning period of postnatal growth.

\section{MATERIALS AND METHODS}

\section{Animals, Management, and Dietary Allowances}

This study was completed at Massey University, Dairy Unit No. 4, Palmerston North, Manawatu, New Zealand, between mid August and early December 2017, when the mean relative humidity was $68.5 \%$ and temperature was $15.7^{\circ} \mathrm{C}$, ranging from 5 to $28^{\circ} \mathrm{C}$. All procedures were undertaken under the approval of Massey University Animal Ethics Committee, which was granted before the commencement of the study.

A total of 60 dairy-bred heifer calves (Friesian cross), born in a spring calving dairy herd, were collected within $6( \pm 3) \mathrm{h}$ of life from the calving paddocks, which were within $0.5 \mathrm{~km}$ of the calf unit. On collection, all the calves had their umbilici treated with a $7 \%$ iodine solution and again on arrival at the calf unit. Calves were offered $3 \mathrm{~L}$ of fresh first-day milking colostrum with a minimum of $50 \mathrm{~g} / \mathrm{L} \mathrm{IgG}$ assessed using a Reichert AR 200 digital hand-held refract meter (Reichert Inc., Depew, NY) within the first 6 to $12 \mathrm{~h}$ of birth and then offered transition milk at 4 to $5 \mathrm{~L} /$ calf per day (i.e., $10 \%$ of birthweight) for the following $3 \mathrm{~d}$ of life. Colostrum was pooled from cows and fed individually to calves from bottles for the first $2 \mathrm{~d}$ and transition milk was fed from buckets from d 2 .

Blood samples were collected from the jugular vein at d 4 when calves were first weighed and analyzed for total serum protein levels and IgG concentration by radial immune diffusion assay (VMRD Inc., Pullman, WA) to ensure adequate intake of colostrum. After weighing, calves were assigned to 1 of 2 milk feeding groups ( $\mathrm{n}=30$ per group). One group was assigned to be offered whole, unpasteurized milk at a restricted volume $(4 \mathrm{~L}$ per day $=10 \%$ of birth weight) and the second group was assigned to be offered $8 \mathrm{~L}$ per day (20\% of birth weight) during the preweaning period of postnatal growth. Due to calf shed design and Massey University Animal Ethics Committee welfare regulations, each calf pen was assigned to a feeding group with 30 calves per pen.

Calves were offered their respective milk diet on an individual basis, twice daily at 12 -h intervals, using an automated calf-feeding system (made by Holm and Laue and supplied by Bell-Booth, Palmerston North, New Zealand) fitted with one feed station per pen that had electronic individual calf identification and calf weighing capability. In addition to the milk diets, starter grain (energy: $12.5 \mathrm{MJ}$ of $\mathrm{ME} / \mathrm{kg}$ of $\mathrm{DM}$; DM: $86.5 \%$; CP: $20.1 \%$ of DM; NDF: $15.6 \%$ of DM, GrowUp-20, NRM Ltd., Auckland, New Zealand) and hay were introduced after the first week, and after wk 3 , the starter grain was available ad libitum. Fresh, clean water was available ad libitum throughout the study. The amount of starter grain consumed was calculated on a per pen basis each day from the amount offered and the residue remaining. The amount of hay consumed was not measured. One calf was removed from the trial because it refused to drink from the milk feeding machine.

Each group of calves were housed together on a bedding of deep litter barley straw at an allocation of 2.5 $\mathrm{m}^{2}$ space per calf under a single-span roof in a naturally ventilated building. The bedding, water, starter, and hay were replenished twice daily as required. Body weight was recorded weekly until weaning. All calves were weaned when they attained a predetermined live weight of $90 \mathrm{~kg}$, which was automatically carried out by the Holm and Laue milk machine, which reduced the volume of milk offered to each calf by $0.4 \mathrm{~L} / \mathrm{d}$ over a 10- to 14-d period. 


\section{Ultrasonography}

Ultrasonography was performed on each quarter of each calf's mammary gland at 1 wk of age (scan 1$)$ and at 11 to 12 (weaning) wk of age (scan 2). Ultrasound images of each quarter of the mammary glands of all animals were captured in a perpendicular plane parallel to a calf's body using a using a SonoSite M-Turbo scanner with a $5-\mathrm{MHz}, 65-\mathrm{mm}$ sectorial probe (Fujifilm, Greenwood, SC) using the minimum pressure required to capture images. Investigators taking ultrasound measurements were blinded to the feeding groups during scanning and subsequent analyses.

At the first ultrasound assessment (scan 1), calves were manually restrained on a deep straw litter bed on their backs to expose their teats and, to minimize irritation of young skin, methanol was used to make a sonic contact. At scan 2, food-grade canola oil was used to make sonic contact and images were captured from the rear of each calf, which remained standing while being restrained in a squeeze chute. After capturing images, scoring was facilitated by collating animal number, image data, and live links to the images in Excel (Microsoft Office Professional Plus 2013, Microsoft Corp., Redmond, WA). A total of 2,166 images were captured and these were assessed to select the clearest 1,070 images, which were equivalent of one image per quarter for the measurement. Images were displayed on a computer monitor and a ruler was used to measure total mammary gland depth, parenchymal depth, and fat pad depth in millimeters directly off the screen. To standardize the assessment, selected images were used to construct representative reference score sheets (available on request). These reference sheets were used to minimize cognitive drift (changes in the scorer's interpretation of the images).

Key features could be discerned within glands using ultrasound in scan 1 (Figure 1). However, a clear boundary between PAR and MFP was often lacking due to signal fade-out in many images at scan 2 in which the sectorial transducer was less effective at showing the total gland depth and other key features. In addition, it was possible that some of the fat pad was unidentified in images of larger glands. However, the same scoring criteria were applied across all images and glands by the same operator, who was blinded to the feeding groups, thereby removing any potential bias. Therefore, we developed criteria to assess the proportions of PAR and MFP using a conservative and a liberal scoring method using a scan depth that captured the deepest and most informative image. This method relied on the ability of an experienced image scorer to interpret and distinguish patterns and lines in the varying intensi-
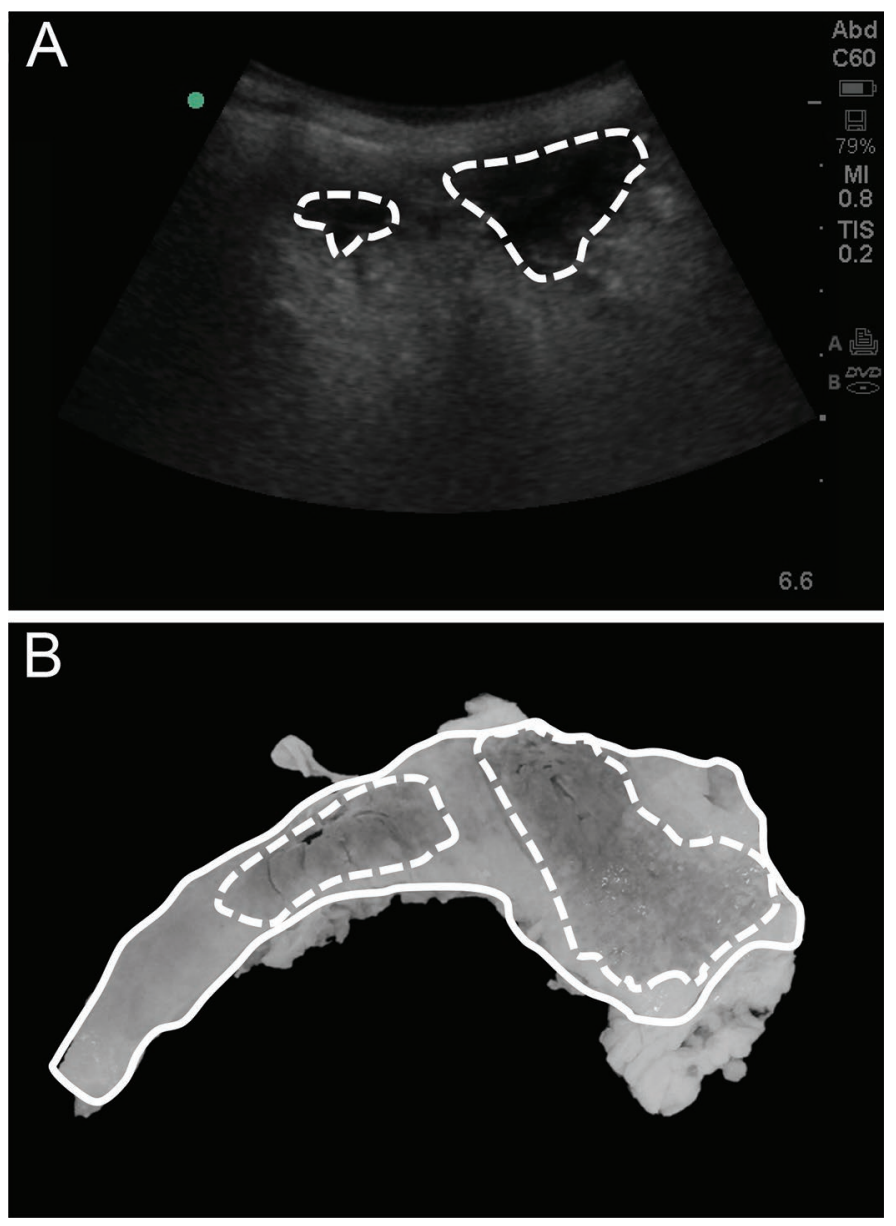

Figure 1. A. Ultrasound image with capture of front (right side) and rear (left side) glands from a nulliparous heifer. Dashed lines denote the cisternal area. The image is not a literal representation of the anatomy as the sectorial transducer splays out the returned image the deeper it goes into the tissue. The top edge of the tissue is near the edge of the parenchyma. B. Gross anatomy image of the same mammary gland and a comparable parenchyma (PAR; dashed lines) and mammary fat pad (MFP; solid line) delineated.

ties of the greyscale images. In the conservative scoring method, the most intense parts of the images were used to decide which demarcations to use to make the measurements (Figure 2A, 2C). In the liberal scoring method, consistent, but less intense transitions in the gray scale were used as demarcations (Figure 2B, 2D).

\section{Statistical Methodology}

Average daily gain was calculated for the first $21 \mathrm{~d}$, $56 \mathrm{~d}$, and for all days to weaning from BW measurements over those periods using the SLOPE function in Microsoft Excel.

Data for scan 1 are uncorrected, whereas those for scan 2 have data for scan 1 deducted to correct for 
differences at the start of the study. To account for different sizes of glands among heifers, the ratio of PAR: MFP was assessed.

Data were loaded into $\mathrm{R}$ version 3.5.1 (R Core Team., 2018). Square root transformation was used for the ultrasound measurements when all factors including teat group to ensure the normality of the small groups of data were required for REML. The REML was performed using the lme4 $\mathrm{R}$ package version 1.1-21 (Bates et al., 2019). For the inter- and intra-scanning time comparisons within teat groups (front and back), type II ANOVA were performed with ADG used as a covariate using the "ANOVA" function of the "car" package version 3.0-2 (Fox and Weisberg, 2018). This was to account for the possibility that differences in rate of growth between feeding groups would influence mammary development. Plots from ANOVA were produced using the "predictmeans" package (Luo et al., 2014).

The ultrasound data were examined at 3 levels: (1) average of all glands per animal (REML on animal averages) to detect any general trends, (2) full REML model including individual glands, but paired for front and back glands, and (3) differences of gland groups between scanning rounds to see if changes were constant.

\section{RESULTS}

Heifer calves offered $8 \mathrm{~L}$ of whole milk per day grew at a faster rate of gain at $21 \mathrm{~d}, 56 \mathrm{~d}$, and throughout preweaning and were weaned $8 \mathrm{~d}$ earlier than calves fed at $4 \mathrm{~L}$ of whole milk per day during the preweaning period (Table 1). In contrast, the group fed $8 \mathrm{~L}$ of whole milk per day consumed about half the starter grain compared with the group offered $4 \mathrm{~L}$ of whole milk per day throughout the preweaning period (Table 1).

Entire mammary glands were rarely captured in images taken at the second scan. Therefore, the depth of the mammary glands and their components were used as a proxy for mammary volumes. Ultrasound images were assessed for depths of PAR and MFP tissues alone and for total tissue depth. The rear glands tended to have a greater total tissue depth and of PAR and MFP compared with the front glands. This was clear at scan 2 using the conservative scoring method (Figure 3A). The differences were similar for measurements of PAR and MFP, but less distinct for total depth of the gland using the liberal scoring method (Figure 3B).

There was a greater depth of MFP, but no effect on the depth of PAR in mammary glands of heifers offered
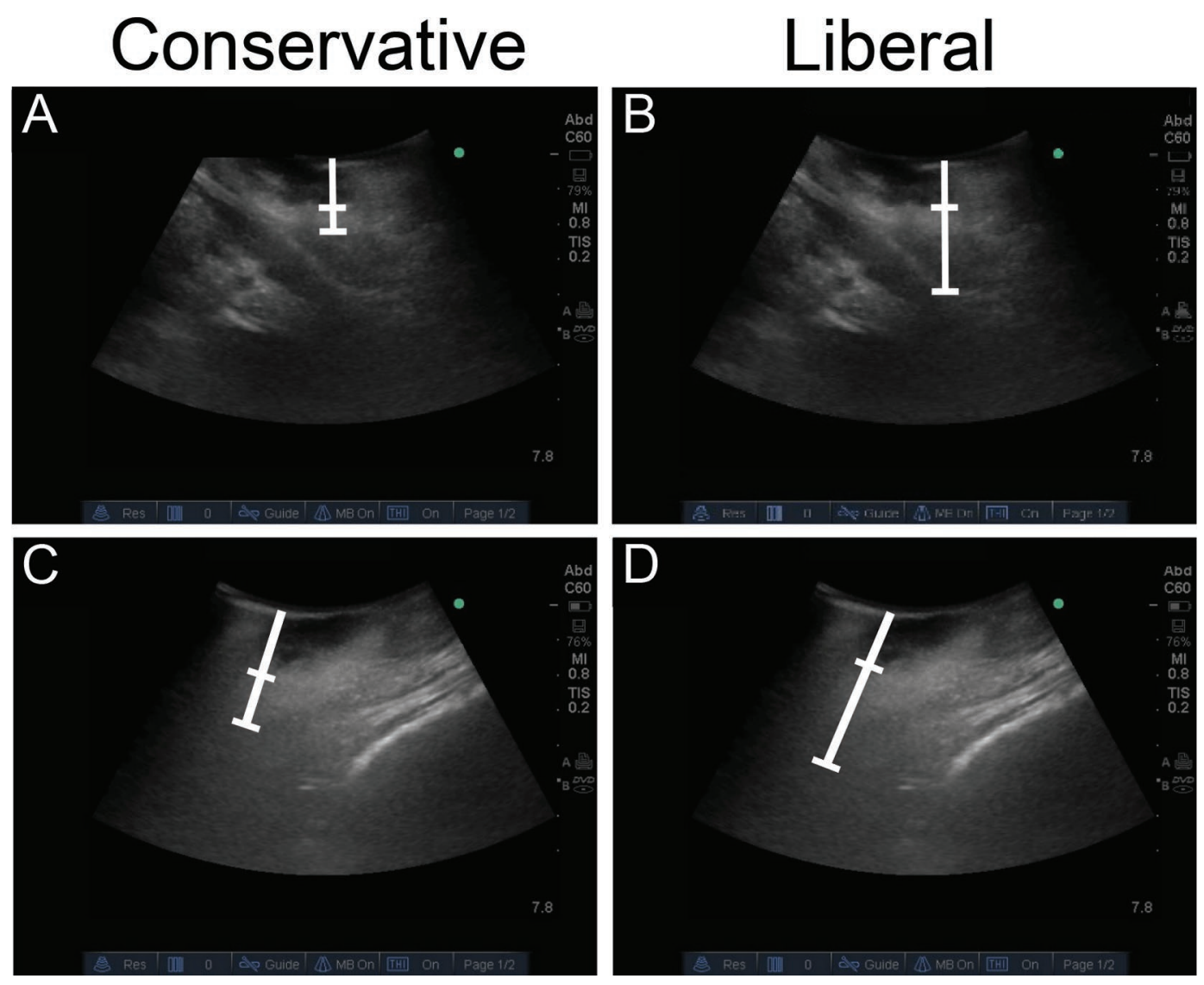

Figure 2. Examples of conservative (A and $\mathrm{C}$ ) and liberal (B and D) scoring demarcations on images taken from two 12-wk-old heifers. 
Table 1. Mean ( \pm SEM) BW at $3 \mathrm{~d}$ and at weaning, time to weaning, ADG to $21 \mathrm{~d}, 56 \mathrm{~d}$ and to weaning, and the average amount of starter grain consumed on a pen basis per head per day for the same time periods ${ }^{1}$

\begin{tabular}{|c|c|c|c|}
\hline \multirow[b]{2}{*}{ Item } & \multicolumn{2}{|c|}{ Whole milk (L/d) } & \multirow[b]{2}{*}{$P$-value } \\
\hline & 4 & 8 & \\
\hline Initial live weight at d $4(\mathrm{~kg})$ & $34.3 \pm 0.7$ & $35.5 \pm 0.8$ & NS \\
\hline Weaning weight $(\mathrm{kg})$ & $104.2 \pm 1.5$ & $105.0 \pm 1.4$ & NS \\
\hline Days to weaning & $87.1 \pm 1.5$ & $79.9 \pm 1.3$ & $<0.001$ \\
\hline $\mathrm{ADG}$ to $21 \mathrm{~d}(\mathrm{~kg} / \mathrm{d})$ & $0.68 \pm 0.11$ & $0.88 \pm 0.18$ & $<0.001$ \\
\hline ADG to $56 \mathrm{~d}(\mathrm{~kg} / \mathrm{d})$ & $0.73 \pm 0.10$ & $0.85 \pm 0.07$ & $<0.001$ \\
\hline $\mathrm{ADG}(\mathrm{kg} / \mathrm{d})$ & $0.81 \pm 0.09$ & $0.86 \pm 0.06$ & $<0.05$ \\
\hline Starter grain consumed to $21 \mathrm{~d}$ (kg/head per day) & $0.41 \pm 0.11$ & $0.12 \pm 0.08$ & $<0.001$ \\
\hline Starter grain consumed to $56 \mathrm{~d}$ ( $\mathrm{kg} /$ head per day) & $0.96 \pm 0.63$ & $0.39 \pm 0.36$ & $<0.001$ \\
\hline Starter grain consumed to weaning (kg/head per day) & $1.11 \pm 0.62$ & $0.45 \pm 0.36$ & $<0.001$ \\
\hline
\end{tabular}

8 L whole milk per day compared with those offered $4 \mathrm{~L}$ per d (Figure 3). As a consequence, there was a lower ratio of PAR:MFP in mammary glands of heifers consuming the higher volume of milk (Figure 4). Good agreement was observed between the conservative and liberal scores for the ratio of PAR:MFP and both scoring methods showed greater PAR:MFP at weaning in the group fed $4 \mathrm{~L}$ of whole milk per day compared with the group offered $8 \mathrm{~L}$ of whole milk per day (Figure 4).

Using the conservative scoring method, calves offered $8 \mathrm{~L}$ of whole milk per day had a $40 \%$ smaller ratio of PAR:MFP in the front glands at weaning compared with calves offered $4 \mathrm{~L}$ of whole milk per day (Figure 4A). Similarly, the liberal scoring method showed that calves offered $8 \mathrm{~L}$ of whole milk per day had a $61 \%$ smaller ratio of PAR:MFP in the front glands and a $58 \%$ smaller ratio in the rear glands at weaning than calves offered $4 \mathrm{~L}$ of whole milk per day. Overall, the differences between PAR:MFP were more marked in the front glands and less distinct in the rear glands.

\section{DISCUSSION}

Two methods of ultrasonography were developed here and each identified similar differences in PAR and MFP in young calves in response to feeding 2 different volumes of whole milk during preweaning. Although ultrasound is useful by being noninvasive and, therefore, repeat measurements can be made on the same heifers, an obvious shortcoming is not being able to accurately discriminate between PAR and MFP because the resolution is insufficient to capture the highly branched structure of the PAR (Akers, 2017). Therefore, there will be less precision using the technique than when the PAR and MFP are dissected from glands and weighed after harvesting. Despite this limitation, other investigators have indicated that gross demarcations between PAR and MFP can be identified using the intensity of pixel brightness [PAR is hypoechoic (black) and MFP is hyperechoic (white)] to aid tracing the outlines of PAR using software (Esselburn et al., 2015; Albino et al., 2017; Furini et al., 2018). For the current study, we reasoned that using software to measure the volume of mammary glands from traced outlines was not necessary because (1) the tracing method also relies on the ability of an observer to interpret where the demarcations are, (2) a single image will usually not capture the entire gland of larger glands and, therefore, superimposed images are required, and finally, (3) the tracing method is very time consuming. Therefore, we considered that the depth of mammary glands and that of its components is a reasonable proxy for volumes. Moreover, the advantage of the methods developed here is in speed of acquisition because the data can be obtained at the time of scanning, rather than after postprocessing of images.

The size of the gland does affect the resolution of ultrasonography. The clearest images were obtained in young animals at $\sim 1 \mathrm{wk}$ of age and in most animals at weaning. However, we also tested the method on the same heifers at $20 \mathrm{wk}$ and observed less distinct images, which were harder to interpret due to fade out of the signal intensity (data not shown). SonoSite equipment (Fujifilm, Greenwood, SC) advises (2017 personal communication) that although lipid (e.g., mammary fat pad) is more sonically dense and should appear brighter in the image, it also rapidly attenuates the signal and, hence, reduces the brightness of the reflected signal. Therefore, clear demarcation lines such as the mammary fat pad and abdominal wall were not visible in the images taken of most of the older animals at 19 to 20 wk of age.

A higher level of nutrition offered to calves and, thus, a greater rate of growth during preweaning and early postweaning are now thought to be a critical determinants in the development of prepubertal mammary glands, earlier attainment of puberty (Soberon and Van Amburgh, 2017; Van Amburgh et al., 2019), a younger 

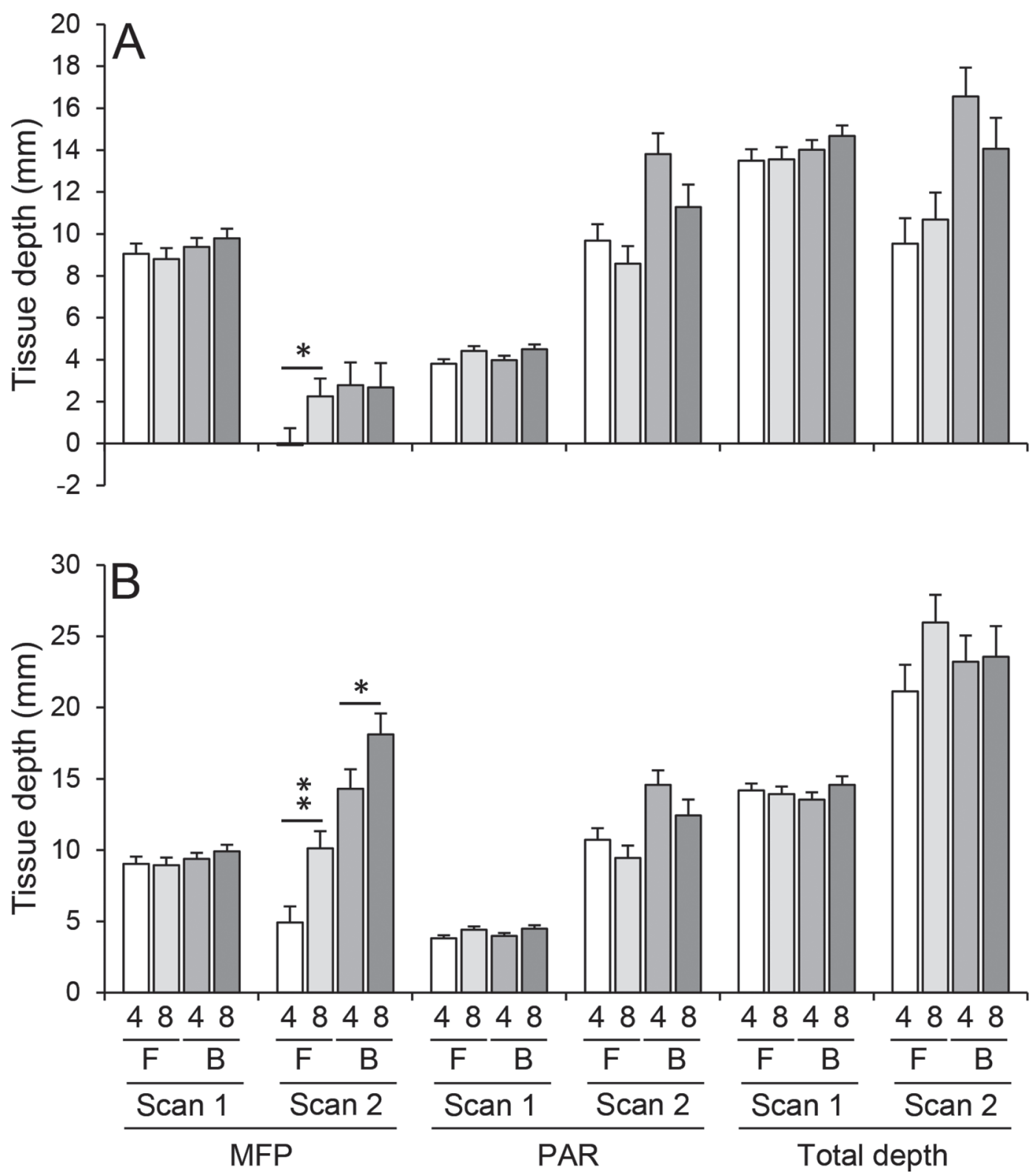

Figure 3. Tissue depth ascertained from ultrasound measurements for mammary fat pad (MFP), parenchyma (PAR), and total mammary depth for front and rear glands at scan rounds $1(1 \mathrm{wk})$ and $2(12 \mathrm{wk})$ for calves offered either 4 or $8 \mathrm{~L}$ of whole milk per day using the conservative (A) and liberal (B) scoring methods. Data for scan 1 are uncorrected, whereas those for scan 2 have data from scan 1 deducted to correct for differences at the start of the study. In addition. ADG was used as a covariate to account for differences in the rate of growth. Asterisks and symbols indicate significance $\left({ }^{*} P<0.05,{ }^{*} P<0.01\right) .4=4 \mathrm{~L} / \mathrm{d}$ of whole milk; $8=8 \mathrm{~L} / \mathrm{d}$ of whole milk; $\mathrm{F}=$ front glands; B $=$ rear glands. Values are given as mean \pm SEM.

age at first calving and increased yields of milk at first lactation (Soberon et al., 2012; Soberon and Van Amburgh, 2013). Indeed, it has been reported that cows will produce $850 \mathrm{~kg}$ more milk over a lactation for every extra kilogram gained over the preweaning period and $235 \mathrm{~kg}$ more milk for every Mcal of ME intake above maintenance (Soberon et al., 2012). In this study, heifers offered $8 \mathrm{~L}$ of whole milk per day had a greater preweaning rate of growth, reached weaning weight sooner, and were weaned $8 \mathrm{~d}$ earlier than calves fed 4 L of whole milk per day. Therefore, our data on growth agree with the notion that higher levels of nutrition might be beneficial to lifetime productivity of replacement heifers in the herd (Soberon et al., 2012; Soberon and Van Amburgh, 2013; Van Amburgh et al., 2019).

In addition to inducing a faster rate of growth, an increased level of nutrition is not detrimental to growth of mammary glands during the preweaning period 
(Brown et al., 2005; Meyer et al., 2006a,b; Daniels et al., 2009a; Geiger et al., 2016a). Indeed, both PAR and MFP can increase in size in response to an increased level of nutrition (Brown et al., 2005; Geiger et al., 2016a), whereas it is now understood that growth of PAR is a function of age, not nutrition per se (Meyer et al., 2006a,b). We show here that heifer calves offered $8 \mathrm{~L}$ of whole milk per day have more MFP, when using either the conservative or the liberal scoring methods, while the amount of PAR is unaffected. Therefore, our data are consistent with the premise that growth of PAR is a function of age and that an increased level of nutrition increases growth of MFP (Meyer et al.,
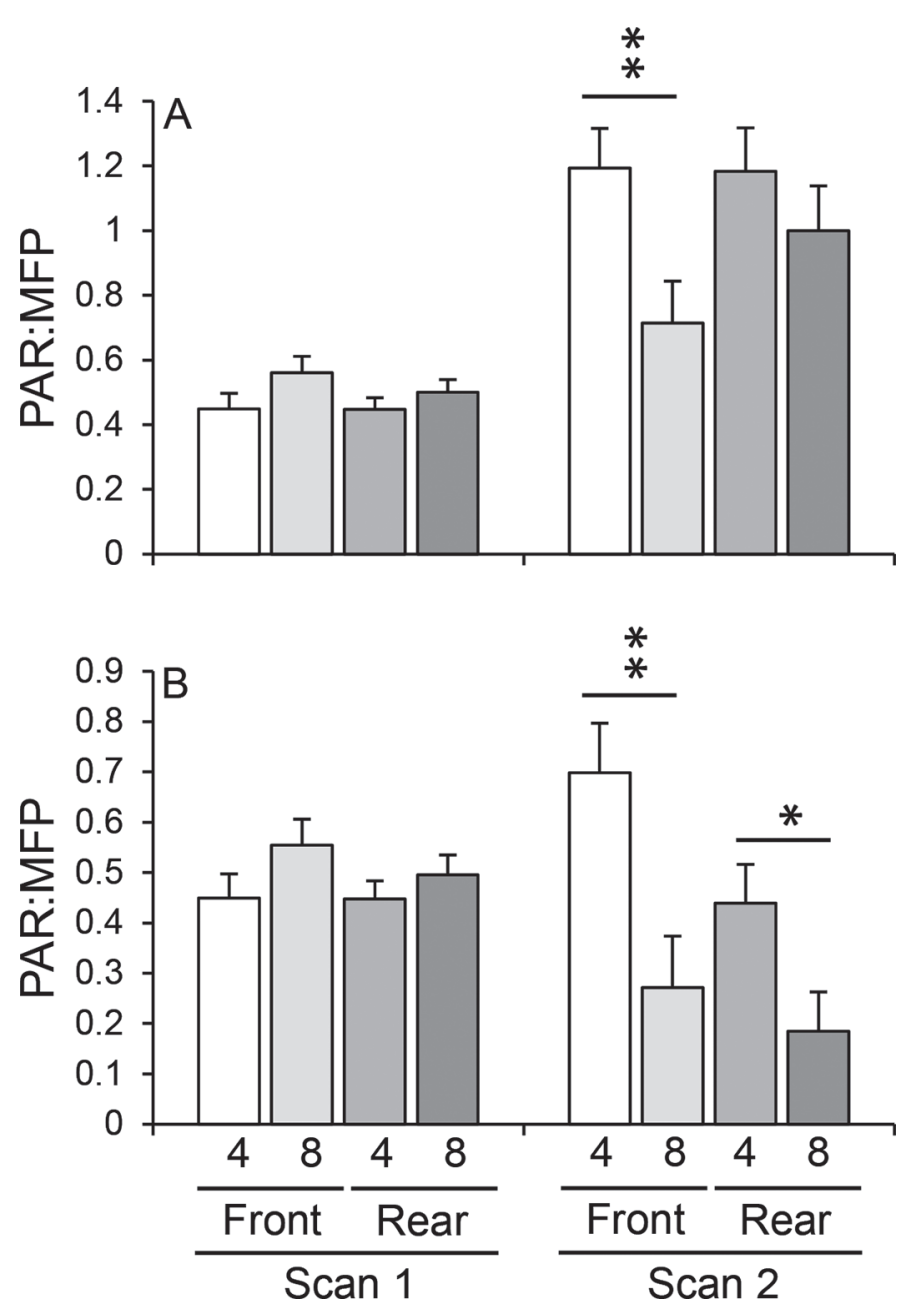

Figure 4. Ratio of parenchyma to mammary fat pad (PAR:MFP) for front and rear glands at scan rounds 1 (1 wk) and 2 (12 wk) for calves offered either 4 or $8 \mathrm{~L}$ of whole milk per day using the conservative (A) and liberal (B) scoring methods. Data for scan 1 are uncorrected, whereas data for scan 2 have data from scan 1 deducted to correct for differences at the start of the study. In addition, ADG was used as a covariate to account for differences in the rate of growth. Asterisks and symbols indicate significance $\left({ }^{*} P<0.05,{ }^{* *} P<0.01\right)$. $4=4 \mathrm{~L} / \mathrm{d}$ of whole milk; $8=8 \mathrm{~L} / \mathrm{d}$ of whole milk. Values are given as mean \pm SEM. 2006a,b). As a consequence, the ratio of PAR to MFP is reduced in heifers offered $8 \mathrm{~L}$ versus heifers offered 4 $\mathrm{L}$ of whole milk per day. The greater tissue depth of the rear glands is consistent with greater development and size of those glands relative to the front glands, which becomes apparent before weaning (Turner, 1952). The rear quarters are $60 \%$ heavier, have larger cisterns, and secrete $60 \%$ more milk during lactation than the front quarters (Petersen, 1942; Ayadi et al., 2003).

There might be different effects of the energy and protein contents of whole milk and milk replacer formulations that differentially affect PAR and MFP at different stages of growth before puberty. For example, while increasing the amount of milk replacer offered preweaning substantially increased the mass of both PAR and MFP (Geiger et al., 2016a; Soberon and Van Amburgh, 2017), increasing the protein content of milk replacer increased the percent of PAR in the first 8 wk of life, while having no effect from 8 to 14 wk of age (Brown et al., 2005). Conversely, increasing the energy content in the diet increased the amount of MFP from 8 to 14 wk of age (Brown et al., 2005) and up to puberty without affecting the growth of PAR when corrected for age (Meyer et al., 2006a,b). Therefore, a higher protein content, rather than an increased energy content of milk, might improve rates of growth of both calf (lean growth) and PAR.

In New Zealand, the majority of dairy calves are reared on whole milk from cows grazing at pasture that produce a relatively high fat-to-protein ratio of 1.25:1 (Margerison et al., 2013; DairyNZ, 2018), which is a little higher than for Holstein cows fed TMR in the United States (1.21:1; USCDCB, 2018). Therefore, increasing the protein-to-fat ratio, rather than energy concentration of the diet alone, might be a means to further improve lactation performance not only of growth of calves, but also of growth of the PAR relative to the MFP as reported by others (Brown et al., 2005), which is in accordance with the postulate proposed by Silva et al. (2002). Naturally, as energy requirements increase above maintenance, so too will the requirement for protein. The specific ratios of protein to other nutrients might be an important determinant in the growth of PAR relative to MFP. As an example, a recent study has shown that the mammary gland transcriptome is differentially affected by restricted and elevated levels of nutrition (Hare et al., 2019). Specific cell types are known to respond to nutrition and understanding these signals could be critical to identifying optimal nutrition regimens in the preweaning period (Capuco, 2007; Soberon and Van Amburgh, 2017). Therefore, we reported the amount of starter grain consumed up to 21 $\mathrm{d}$ before it was offered ad libitum and up to $56 \mathrm{~d}$ when others reported a greater effect of protein content in 
the diet on growth of PAR (Brown et al., 2005). While ADG remained higher throughout the preweaning period in the group offered $8 \mathrm{~L}$ of whole milk per day, the ADG progressively increased in the group offered whole milk at $4 \mathrm{~L} / \mathrm{d}$. It is possible that offering higher protein supplements offsets the higher fat-to-protein ratio of whole milk and the lower volume of milk offered to heifers offered whole milk at $4 \mathrm{~L} / \mathrm{d}$ at a critical time during preweaning and stimulates greater growth of PAR, or the ratio of PAR:MFP. In contrast to our findings, others report that first lactation performance was not different between heifers reared under a near-identical preweaning program (4 vs. $8 \mathrm{~L}$ of whole milk/d) to that used in our study (Kiezebrink et al., 2015). The major difference in the preweaning program was that we weaned calves at $90 \mathrm{~kg}$, at about 12 wk of age, whereas in the study of Kiezebrink et al. (2015), calves were weaning at 78 to $86 \mathrm{~kg}$ after $8 \mathrm{wk}$ for the 4 - and 8 -L groups, respectively. Growth of mammary glands was not assessed in that study.

Our data are consistent with the notion that there is an optimal developmental window during which growth of components in mammary glands (at least the MFP) are sensitive to nutrition during prepubertal growth, which may program the gland for increased lifetime performance (Soberon et al., 2012). The current study suggests that the use of the ultrasound methods developed here may be a valuable tool to appraise the effects of different dietary regimens on growth of PAR and MFP during preweaning, which would aid in the development of nutritional strategies for rearing calves and to determine if these changes have any effect on subsequent lactations. Finding the right formulation and dietary supplement might provide an improved diet and a means to rear higher-performing and more feed-efficient dairy cows.

\section{CONCLUSIONS}

Ultrasonography has some limitations but has a significant advantage over other measurement techniques because it is noninvasive and the animal does not have to be killed in order to measure mammary tissues. Despite the faster rates of growth in calves offered $8 \mathrm{~L} / \mathrm{d}$ of milk/d, the ratio of PAR:MFP depth was $40 \%$ less at weaning compared with calves offered $4 \mathrm{~L}$ of milk/d. Rear glands were less impaired. This research will contribute to the developing potential of ultrasound, along with PAR and MFP scoring methods, as a noninvasive diagnostic tool that would facilitate the evaluation of preweaning nutrition on the development of mammary glands in live heifers and on subsequent lactation performance, along with feed conversion efficiency.

\section{ACKNOWLEDGMENTS}

We thank technical staff at Massey University and at Dairy Unit No. 4 (Palmerston North, New Zealand) for their support, facilities, and supplying calves and managing heifers for the completion of this research. A grant (A18003) from the Agricultural and Marketing Research and Development Trust (AGMARDT) partially funded the work, along with funding from Bell-Booth Ltd., Palmerston North, New Zealand. We thank Gerardo Caja of the Group of Ruminant Research (G2R), Autonomous University of Barcelona, Bellaterra (Spain), for introducing us to and training us in the use of ultrasonography and to Shane Leath, AgResearch, for designing a method for integrating images, animal information, and measurements. We also thank internal reviewers, not associated with the work, for constructive and critical comments on the manuscript. The authors confirm that there are no conflicts of interest.

\section{REFERENCES}

Akers, R. M. 2017. A 100-Year Review: Mammary development and lactation. J. Dairy Sci. 100:10332-10352. https://doi.org/10.3168/ jds.2017-12983.

Albino, R. L., S. E. F. Guimaraes, K. M. Daniels, M. M. S. Fontes, A. F. Machado, G. B. Dos Santos, and M. I. Marcondes. 2017. Technical note: Mammary gland ultrasonography to evaluate mammary parenchymal composition in prepubertal heifers. J. Dairy Sci. 100:1588-1591. https://doi.org/10.3168/jds.2016-11668.

Albino, R. L., M. I. Marcondes, R. M. Akers, E. Detmann, B. C. Carvalho, and T. E. Silva. 2015. Mammary gland development of dairy heifers fed diets containing increasing levels of metabolisable protein: metabolisable energy. J. Dairy Res. 82:113-120. https:// doi.org/10.1017/S0022029914000697.

Ayadi, M., G. Caja, X. Such, and C. H. Knight. 2003. Use of ultrasonography to estimate cistern size and milk storage at different milking intervals in the udder of dairy cows. J. Dairy Res. 70:1-7. https://doi.org/10.1017/S0022029902005873.

Bates, D., M. Maechler, B. Bolker, S. Walker, R. Bojesen, H. Singmann, B. Dai, F. Schleipl, G. Grothendieck, P. Green, and J. Fox. 2019. Linear Mixed-Effects Models using 'Eigen' and S4. 1.1-21 ed. R Foundation for Statistical Computing, Vienna, Austria.

Brown, E. G., M. J. Vandehaar, K. M. Daniels, J. S. Liesman, L. T. Chapin, J. W. Forrest, R. M. Akers, R. E. Pearson, and M. S. Nielsen. 2005. Effect of increasing energy and protein intake on mammary development in heifer calves. J. Dairy Sci. 88:595-603. https://doi.org/10.3168/jds.S0022-0302(05)72723-5.

Bruckmaier, R. M., and J. W. Blum. 1992. B-mode ultrasonography of mammary glands of cows, goats and sheep during alpha- and beta-adrenergic agonist and oxytocin administration. J. Dairy Res. 59:151-159. https://doi.org/10.1017/S0022029900030399.

Capuco, A. V. 2007. Identification of putative bovine mammary epithelial stem cells by their retention of labeled DNA strands. Exp. Biol. Med. (Maywood) 232:1381-1390. https://doi.org/10.3181/ 0703-RM-58.

Collier, R. J., Y. Xiao, and D. E. Bauman. 2017. Regulation of factors affecting milk yield. Pages $1-15$ in Nutrients in Dairy and Their Implications for Health and Disease. Elsevier.

DairyNZ. 2018. New Zealand Dairy Statistics 2017-2018. Pages 1-52. Livestock Improvement Corporation and DairyNZ Ltd.

Daniels, K. M., A. V. Capuco, M. L. McGilliard, R. E. James, and R. M. Akers. 2009a. Effects of milk replacer formulation on measures 
of mammary growth and composition in Holstein heifers. J. Dairy Sci. 92:5937-5950. https://doi.org/10.3168/jds.2008-1959.

Daniels, K. M., M. L. McGilliard, M. J. Meyer, M. E. Van Amburgh, A. V. Capuco, and R. M. Akers. 2009b. Effects of body weight and nutrition on histological mammary development in Holstein heifers. J. Dairy Sci. 92:499-505. https://doi.org/10.3168/jds.2008 -1007 .

Ellis, S., and A. V. Capuco. 2002. Cell proliferation in bovine mammary epithelium: Identification of the primary proliferative cell population. Tissue Cell 34:155-163. https://doi.org/10.1016/ S0040-8166(02)00025-3.

Esselburn, K. M., T. M. Hill, H. G. Bateman 2nd, F. L. Fluharty, S. J. Moeller, K. M. O'Diam, and K. M. Daniels. 2015. Examination of weekly mammary parenchymal area by ultrasound, mammary mass, and composition in Holstein heifers reared on 1 of 3 diets from birth to 2 months of age. J. Dairy Sci. 98:5280-5293. https:/ /doi.org/10.3168/jds.2014-9061.

Fox, J., and S. Weisberg. 2018. An R Companion to Applied Regression. 3rd. vol. SAGE Publications, Thousand Oaks, CA.

Franz, S., M. Floek, and M. Hofmann-Parisot. 2009. Ultrasonography of the bovine udder and teat. Vet. Clin. North Am. Food Anim. Pract. 25:669-685. https://doi.org/10.1016/j.cvfa.2009.07.007.

Furini, P. M., R. A. Azevedo, S. R. A. Rufino, F. S. Machado, M. M. Campos, L. G. R. Pereira, T. R. Tomich, B. C. Carvalho, G. B. Santos, and S. G. Coelho. 2018. The effects of increasing amounts of milk replacer powder added to whole milk on mammary gland measurements using ultrasound in dairy heifers. J. Dairy Sci. 101:767-773. https://doi.org/10.3168/jds.2017-12798.

Geiger, A. J., C. L. M. Parsons, and R. M. Akers. 2016a. Feeding a higher plane of nutrition and providing exogenous estrogen increases mammary gland development in Holstein heifer calves. J. Dairy Sci. 99:7642-7653. https://doi.org/10.3168/jds.2016-11283.

Geiger, A. J., C. L. M. Parsons, R. E. James, and R. M. Akers. 2016b. Growth, intake, and health of Holstein heifer calves fed an enhanced preweaning diet with or without postweaning exogenous estrogen. J. Dairy Sci. 99:3995-4004. https://doi.org/10.3168/jds .2015-10405.

Hare, K. S., L. N. Leal, J. M. Romao, G. J. Hooiveld, F. Soberon, H. Berends, M. E. Van Amburgh, J. Martin-Tereso, and M. A. Steele. 2019. Preweaning nutrient supply alters mammary gland transcriptome expression relating to morphology, lipid accumulation, DNA synthesis, and RNA expression in Holstein heifer calves. J. Dairy Sci. 102:2618-2630. https://doi.org/10.3168/jds.2018-15699.

Khan, M. A., H. J. Lee, W. S. Lee, H. S. Kim, S. B. Kim, K. S. Ki, J. K. Ha, H. G. Lee, and Y. J. Choi. 2007. Pre- and postweaning performance of Holstein female calves fed milk through step-down and conventional methods. J. Dairy Sci. 90:876-885. https://doi .org/10.3168/jds.S0022-0302(07)71571-0.

Kiezebrink, D. J., A. M. Edwards, T. C. Wright, J. P. Cant, and V. R. Osborne. 2015. Effect of enhanced whole-milk feeding in calves on subsequent first-lactation performance. J. Dairy Sci. 98:349-356. https://doi.org/10.3168/jds.2014-7959.

Knight, C. H., and M. Peaker. 1982. Development of the mammary gland. J. Reprod. Fertil. 65:521-536. https://doi.org/10.1530/jrf .0 .0650521 .

Korst, M., C. Koch, J. Kesser, U. Muller, F. J. Romberg, J. Rehage, K. Eder, and H. Sauerwein. 2017. Different milk feeding intensities during the first 4 weeks of rearing in dairy calves: Part 1: Effects on performance and production from birth over the first lactation. J. Dairy Sci. 100:3096-3108. https://doi.org/10.3168/ jds.2016-11594.

Luo, D., S. Ganesh, and J. Koolaard. 2014. Predictmeans: Calculate predicted means for linear models. R Core Team, ed. R Foundation for Statistical Computing, Vienna, Austria.

Margerison, J. K., A. D. Robarts, and G. W. Reynolds. 2013. The effect of increasing the nutrient and amino acid concentration of milk diets on dairy heifer individual feed intake, growth, development, and lactation performance. J. Dairy Sci. 96:6539-6549. https://doi.org/10.3168/jds.2012-6489.
Meyer, M. J., A. V. Capuco, D. A. Ross, L. M. Lintault, and M. E. Van Amburgh. 2006a. Developmental and nutritional regulation of the prepubertal bovine mammary gland: II. Epithelial cell proliferation, parenchymal accretion rate, and allometric growth. J. Dairy Sci. 89:4298-4304. https://doi.org/10.3168/jds.S0022 $-0302(06) 72476-6$

Meyer, M. J., A. V. Capuco, D. A. Ross, L. M. Lintault, and M. E. Van Amburgh. 2006b. Developmental and nutritional regulation of the prepubertal heifer mammary gland: I. Parenchyma and fat pad mass and composition. J. Dairy Sci. 89:4289-4297. https://doi .org/10.3168/jds.S0022-0302(06)72475-4.

Moallem, U., D. Werner, H. Lehrer, M. Zachut, L. Livshitz, S. Yakoby, and A. Shamay. 2010. Long-term effects of ad libitum whole milk prior to weaning and prepubertal protein supplementation on skeletal growth rate and first-lactation milk production. J. Dairy Sci. 93:2639-2650. https://doi.org/10.3168/jds.2009-3007.

Nishimura, M., T. Yoshida, S. El-Khodery, M. Miyoshi, H. Furuoka, J. Yasuda, and K. Miyahara. 2011. Ultrasound imaging of mammary glands in dairy heifers at different stages of growth. J. Vet. Med. Sci. 73:19-24. https://doi.org/10.1292/jvms.09-0503.

Petersen, W. E. 1942. The cow's udder. Pages 4-11 in Minnesota Bulletin Vol. 361.

R Core Team. 2018. R: A Language and Environment for Statistical Computing. R Foundation for Statistical Computing, Vienna, Austria.

Sejrsen, K. 1994. Relationships between nutrition, puberty and mammary development in cattle. Proc. Nutr. Soc. 53:103-111. https:// doi.org/10.1079/PNS19940014.

Sejrsen, K., J. T. Huber, H. A. Tucker, and R. M. Akers. 1982. Influence of nutrition of mammary development in pre- and postpubertal heifers. J. Dairy Sci. 65:793-800. https://doi.org/10.3168/jds .S0022-0302(82)82268-6

Sejrsen, K., and S. Purup. 1997. Influence of prepubertal feeding level on milk yield potential of dairy heifers: A review. J. Anim. Sci. 75:828-835. https://doi.org/10.2527/1997.753828x.

Shamay, A., D. Werner, U. Moallem, H. Barash, and I. Bruckental. 2005. Effect of nursing management and skeletal size at weaning on puberty, skeletal growth rate, and milk production during first lactation of dairy heifers. J. Dairy Sci. 88:1460-1469. https://doi .org/10.3168/jds.S0022-0302(05)72814-9.

Silva, L. F., M. J. VandeHaar, B. K. Whitlock, R. P. Radcliff, and H. A. Tucker. 2002. Short communication: relationship between body growth and mammary development in dairy heifers. J. Dairy Sci. 85:2600-2602. https://doi.org/10.3168/jds.S0022-0302(02)74344 -0 .

Soberon, F., E. Raffrenato, R. W. Everett, and M. E. Van Amburgh. 2012. Preweaning milk replacer intake and effects on long-term productivity of dairy calves. J. Dairy Sci. 95:783-793. https://doi .org/10.3168/jds.2011-4391.

Soberon, F., and M. E. Van Amburgh. 2013. Lactation Biology Symposium: The effect of nutrient intake from milk or milk replacer of preweaned dairy calves on lactation milk yield as adults: A meta-analysis of current data. J. Anim. Sci. 91:706-712. https:// doi.org/10.2527/jas.2012-5834.

Soberon, F., and M. E. Van Amburgh. 2017. Effects of preweaning nutrient intake in the developing mammary parenchymal tissue. J. Dairy Sci. 100:4996-5004. https://doi.org/10.3168/jds.2016-11826.

Turner, C. W. 1952. The mammary gland: I. The anatomy of the udder of cattle and domestic animals Vol. 1. Lucas Bros., Columbia, MO.

USCDCB. 2018. Summary of 2018 DHI Herd Averages: DHI Report K-3. United States Council on Dairy Cattle Breeding, Bowie, MD.

Van Amburgh, M. E., F. Soberon, M. J. Meyer, and R. A. Molano. 2019. Symposium review: Integration of postweaning nutrient requirements and supply with composition of growth and mammary development in modern dairy heifers. J. Dairy Sci. 102:3692-3705. https://doi.org/10.3168/jds.2018-15270. 